\title{
Different Polyoxometalate Structures Obtained from the $\mathrm{Na}_{11} \mathrm{H}\left[\mathrm{H}_{(2-\mathrm{x})} \mathrm{Bi}_{2} \mathrm{~W}_{20} \mathrm{O}_{70}\left(\mathrm{HWO}_{3}\right)_{\mathrm{x}}\right] \cdot 46 \mathrm{H}_{2} \mathrm{O}(\mathrm{x}=1.4)$.
}

\author{
Suhair Atta ${ }^{* 1}$, Salim Haddad ${ }^{2}$ Murad AlDamen ${ }^{2}$ \\ ${ }^{1)}$ Department of Chemistry, Faculty of Science, University of Tabuk, Tabuk, Saudi Arabia \\ ${ }^{2)}$ Department of Chemistry, Faculty of Science, the University of Jordan, Amman, Jordan \\ In the supramolecular chemistry world, Polyoxometalates (POMs) are considered as a new family of inorganic \\ molecular containers, construct itself by self-assembly reaction from very small units, to form a cluster with unique \\ structural and properties. three structures reported in this paper - differ in their unit cell parameters and also differ from \\ the well-known - as the result of reaction of the $\mathrm{Na}_{11} \mathrm{H}\left[\mathrm{H}_{(2-\mathrm{x})} \mathrm{Bi}_{2} \mathrm{~W}_{20} \mathrm{O}_{70}\left(\mathrm{HWO}_{3}\right)_{x}\right] \cdot 46 \mathrm{H}_{2} \mathrm{O}(\mathrm{x}=1.4)$ with $\mathrm{Ca}$ ion at different \\ $\mathrm{pH}$ conditions. These structures are $\left[\mathrm{Ca}\left(\mathrm{H}_{2} \mathrm{O}\right)_{7}\right]_{2}\left[\mathrm{Na}\left(\mathrm{H}_{2} \mathrm{O}\right)_{2}\right]_{2}\left[\mathrm{HBi}_{2} \mathrm{~W}_{20} \mathrm{O}_{70}\left(\mathrm{HWO}_{3}\right)\right] .14 \mathrm{H}_{2} \mathrm{O}(1)$, \\ $\mathrm{H}_{2}\left[\mathrm{NH}_{4}\right]_{10}\left[\mathrm{HBi}_{2} \mathrm{~W}_{20} \mathrm{O}_{70}\left(\mathrm{HWO}_{3}\right)\right](2)$, and $\left[\mathrm{NH}_{4}\right]_{6}\left[\mathrm{Na}\left(\mathrm{H}_{2} \mathrm{O}\right)_{4}\right]_{2}\left[\mathrm{Ca}\left(\mathrm{H}_{2} \mathrm{O}\right)_{4}\right]_{2}\left[\mathrm{~W}_{12} \mathrm{O}_{42}\right] .2 \mathrm{H}_{2} \mathrm{O}(3)$. The last one is bismuth-free \\ and it is formed through reassembly of the precursor. Full structural characterization was made by multiple testing \\ techniques such as single-crystal X-ray diffraction, UV-visible spectroscopy, FT-IR, thermogravimetric analysis (TGA), \\ scanning electron microscopy (SEM), and energy-dispersive X-ray spectroscopy (EDS). The single-crystal X-ray \\ diffraction results for the three compounds are as follows:(1), Triclinic, space group P-1, while (2) and (3) crystallize in \\ monoclinic space groups $\mathrm{C} 2 / \mathrm{m}$ and $\mathrm{P} 21 / \mathrm{n}$ respectively.
}

Keywords: sandwich polyoxometalates, Bismuth, crystal structure, inorganic lattice, calcium.

\section{Introduction}

Polyoxometalates (POMs) present themselves as a new special class of intriguing metal-oxygen cluster compounds which are preferably formed by complex self-assembly processes of $\mathrm{W}$, Mo, and V in their high oxidation states. The chemistry of POMs is a rapidly developing field, which present a wide range of properties and applications (Hutin, et al., 2013), (Miras, et al., 2012), (Long, et al., 2010), (Mansergh, et al., 2016), (Liu, et al., 2015), ( Rasmussen, et al., 2016), (Breitwieser, et al., 2016), ( Lai, et al., 2013), among diverse applications, POMs-catalysts for many organic reactions are receiving special attention, (Ni, et al., 2012), (Hasenknopf, 2005), (Chen, et al., 2012), (Hussain, et al., 2016), another applications also determined and studied such as magnetism, (Clemente, et al., 2012), (Kortz, et al., 2009), (Vonci, et al., 2014), water oxidation catalysts and reduction catalysts, (Yu, et al., 2016), (Schwarz, et al., 2016), (Lv, et al., 2013), (Von, et al., 2015), (Rausch, et al., 2014), POMs shown also promising performance in both photo catalytic and electro processes (Evangelisti, et al., 2013). Compared with the large numbers of sandwich polyanions containing Si (IV), P (V) and Ge (IV) as tetrahedrally coordinated heteroatoms, the POMs containing bismuth ion as the heteroatom are largely unexplored. The synthesis and structural characterization of the tungstobismutates are still difficult because of the lone pair of electrons located on the top of the pyramid of coordination. The first tungstobismutates structures synthesized are, $\left[\mathrm{HnXIIIW}_{18} \mathrm{O}_{60}\right]^{(9-\mathrm{n})-}(\mathrm{X}=\mathrm{As}(\mathrm{III}), \mathrm{Sb}(\mathrm{III})$ or Bi(III) ) (Krebs and Klein, 1993), (Ozawa and Sasaki, 1987), (Patrut, et al., 2007), Later a few dimeric tungstobismutates were reported based on $\beta-\mathrm{BiW}_{9} \mathrm{O}_{33}$ units such as $\left[\mathrm{Bi}_{2} \mathrm{~W}_{22} \mathrm{O}_{74}(\mathrm{OH})_{2}\right]^{12-}$ (Rodewald and Jeannin, 1998) and its derivatives $\left[\mathrm{Mn}^{+}\right.$ $\left.{ }^{3}\left(\mathrm{H}_{2} \mathrm{O}\right) \mathrm{x}\left(\mathrm{BiW}_{9} \mathrm{O}_{33}\right)_{2}\right]^{(18-3 \mathrm{n})-}\left(\mathrm{Mn}^{+}=(\mathrm{VO}) \mathrm{II}, \mathrm{x}=0\right.$ and $\mathrm{Mn}^{+}=$CrIII, MnII, FeIII, CoII, NiII, CuII, $\left.\mathrm{x}=3\right)$ (Rusu, et al., 2001), $\mathrm{Na}_{3} \mathrm{H}_{2}\left[\mathrm{Ce}_{3}\left(\mathrm{H}_{2} \mathrm{O}\right)_{18} \mathrm{Bi}_{2} \mathrm{~W}_{22} \mathrm{O}_{76}\right] \cdot 23 \mathrm{H}_{2} \mathrm{O}$ (Wang, et al., 2004). Patrut and coworker reported the synthesis and investigation of a new sodium neutral salt of a hetero polyoxometalate, $\mathrm{Na}_{11} \mathrm{H}\left[\mathrm{H}(2 \mathrm{x}) \mathrm{Bi}_{2} \mathrm{~W}_{20} \mathrm{O}_{70}\left(\mathrm{HWO}_{3}\right)_{\mathrm{x}}\right] \cdot 46 \mathrm{H}_{2} \mathrm{O}(\mathrm{x}=1.4)$ which contains two heteroatoms $\mathrm{Bi}(\mathrm{III})$ with unshared electron pair, and $\mathrm{W}(\mathrm{VI})$ as addend/metal centers. (Patrut, et al., 2010). Recently six new Cu-containing tungstobismutates were synthesized and their structures have been also characterized by Allmen. (Allmen, et al., 2017). However, no calcium tungstobismutates was synthesized or characterized, from this point of view, we are interested to synthesize and characterize a new tungstobismutates POM's with and without the existence of calcium ion, and study the coordination behavior of POMs structures in the presence of this ion.

\section{Materials and Methods}

All chemicals were obtained commercially and used without further purification. The lacunary precursor $\mathrm{Na} a_{11} \mathrm{H}\left[\mathrm{H}_{(2-}\right.$ $\left.{ }_{x} \mathrm{Bi}_{2} \mathrm{~W}_{20} \mathrm{O}_{70}\left(\mathrm{HWO}_{3}\right)_{\mathrm{x}}\right] \cdot 46 \mathrm{H}_{2} \mathrm{O}(\mathrm{x}=1.4)$ was prepared according to published procedures and characterized by FT-IR spectroscopy [30]. UV-Vis data were collected from 200 to $700 \mathrm{~nm}$ at room temperature on a Varian Cary-100 UV/VIS spectrophotometer. 
IR spectra were recorded by a Nicolet Impact 400 Fourier transform infrared Spectrophotometer (Madison, WI) in the $400-4000 \mathrm{~cm}^{-1}$ region. $\mathrm{KBr}$ discs for solid samples were made by grinding $2 \mathrm{mg}$ of the solid sample with about $0.2 \mathrm{~g}$ of $\mathrm{KBr}$. Atomic absorption was recorded on a Varian Atomic Absorption spectrophotometer (Mulgrave, Victoria, Australia) model AA-250 plus. Single-crystal X-ray diffraction data were collected using an Oxford Diffraction Super Nova, Dual, equipped with mirror SuperNova (Mo) X-ray Source $\left(\lambda=0.71073 \mathrm{~A}^{\circ}\right)$ at $173(2) \mathrm{K}$.

For Scanning Electron Microscopy (SEM) dehydrated crystals were molded and attached to $10 \mathrm{~mm}$ metal mounts using carbon tape, and then sputter-coated with platinum under vacuum in an argon atmosphere. The surface morphology of the coated samples was visualized by a Scanning Electron Microscope (FEI Company Inspect, F50/FEG, High Vacuum $<6 \mathrm{e}-4$ Pa, Eindhoven, the Netherlands) with combined Energy Dispersive X-ray Analyzer at a voltage of $\sim 10 \mathrm{keV}$. SEM allowed the identification of any interesting structural features on the seaweed surface with EDS (BRUKER QUANTAX, EDS systems, Bruker AXS Microanalysis Gmbtt, X Flash Detector 410-M Silicon Drift (SDD), Berlin, Germany). $\left[\mathrm{Ca}\left(\mathrm{H}_{2} \mathrm{O}\right)_{7}\right]_{2}\left[\mathrm{Na}_{2}\left(\mathrm{H}_{2} \mathrm{O}\right)_{2}\right]_{2}\left[\mathrm{HBi}_{2} \mathrm{~W}_{20} \mathrm{O}_{70}\left(\mathrm{HWO}_{3}\right)\right] .14 \mathrm{H}_{2} \mathrm{O}(1)$. Solid powder $\mathrm{Na}_{11} \mathrm{H}\left[\mathrm{H}_{(2-\mathrm{x})} \mathrm{Bi}_{2} \mathrm{~W}_{20} \mathrm{O}_{70}\left(\mathrm{HWO}_{3}\right)_{\mathrm{x}}\right] 46 \mathrm{H}_{2} \mathrm{O}(1.49 \mathrm{~g}, 0.225 \mathrm{mmol})$ was dissolved in $10 \mathrm{~mL} \mathrm{H}_{2} \mathrm{O}$ at $80{ }^{\circ} \mathrm{C}$, then added to a solution of $0.08 \mathrm{~g} \mathrm{CaCl}_{2}$ in $10 \mathrm{~mL} \mathrm{H}_{2} \mathrm{O}$, The mixture was stirred for $10 \mathrm{~min}$. To this solution, $0.1 \mathrm{M} \mathrm{HCl}$ was added very slowly with vigorous stirring until $\mathrm{pH}$ reached 5 and remained stable for $5 \mathrm{~min}$. The solution was then stirred for $2 \mathrm{~h}$ under reflux. After cooling to room temperature the turbidity was removed by filtration. Finally, $5 \mathrm{~mL}$ of $1 \mathrm{M}$ of $\mathrm{NH}_{4} \mathrm{Cl}$ was added to the stirred solution, and the solution was left to evaporate slowly at ambient temperature. Stable colorless crystals were separated after 6 days. $\mathrm{H}_{2}\left[\mathrm{NH}_{4}\right]_{10}\left[\mathrm{HBi}_{2} \mathrm{~W}_{20} \mathrm{O}_{70}\left(\mathrm{HWO}_{3}\right)\right](2)$ and $\left[\mathrm{NH}_{4}\right]_{6}\left[\mathrm{Na}\left(\mathrm{H}_{2} \mathrm{O}\right)_{4}\right]_{2}\left[\mathrm{Ca}\left(\mathrm{H}_{2} \mathrm{O}\right)_{4}\right]_{2}\left[\mathrm{~W}_{12} \mathrm{O}_{42}\right] \cdot 2 \mathrm{H}_{2} \mathrm{O}$ (3) were synthesized as Similar procedure as (1) except the $\mathrm{pH}$ was adjusted to 5.5 and 6 respectively. Stable colorless crystals were separated after 4-5 days. All the obtained crystals were stable in solutions. However, they start to decompose slowly due to dehydration.

\section{Results and Discussion}

\subsection{Crystal structure}

Three structures were reported in this work differs in their unit cell and space group, the last one (3) differ from the others, as this structure does not contain bismuth. The structure of compound $1 \mathrm{H}_{66} \mathrm{Ca}_{2} \mathrm{Na}_{2} \mathrm{Bi}_{2} \mathrm{~W}_{21} \mathrm{O}_{105}$ has the lowest lattice symmetry among all. It crystallizes in the space group $P-1$, with one molecular per unit cell, while $\mathbf{2}$ and $\mathbf{3}$ crystallize in monoclinic space groups $C 2 / m$ and $P 21 / \mathrm{n}$ respectively. Table 1 summarizes the crystallographic data for the three crystals. The single-crystal X-ray diffraction analysis (Figure 1) also indicates that the molecular unit for $\mathbf{1}$ is constituted from two asymmetric units. A packing diagram is shown in Figure 2 illustrating the 2-dimensional nature of the structure. And it consists of two identical trilacunary $\beta$ - $\left[\mathrm{BiW}_{9} \mathrm{O}_{33}\right]$ pseudo-Keggin type units in which three $\mathrm{W}_{3} \mathrm{O}_{13}$ groups is turned by $60^{\circ}$ relative to each other.

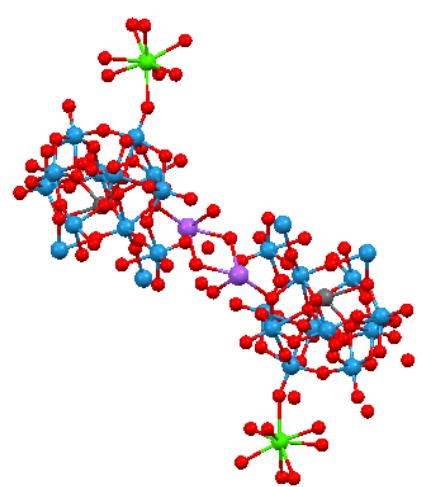

(a)

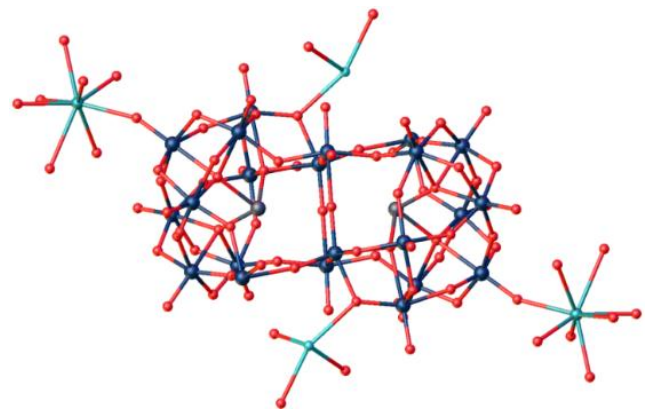

(b)

Fig. 1 (A) Molecular unit in compound (1) view down a-axis (Bi gray, W blue, Na purple, Ca green). (b) The two W9O33Bi subunits joined throw W(8) and W(1). Pending $\mathrm{Ca}$ and $\mathrm{Na}$ attached polyhedra are shown.

The single-crystal X-ray diffraction analysis (Fig. 1) also indicates that the molecular unit for (1) is constituted from two asymmetric 
units. A packing diagram is shown in Figure 2 illustrating the 2-dimensional nature of the structure. And it consists of two identical trilacunary $\beta$ - $\left[\mathrm{BiW}_{9} \mathrm{O}_{33}\right]$ pseudo-Keggin type units in which three $\mathrm{W}_{3} \mathrm{O}_{13}$ groups is turned by $60^{\circ}$ relative to each other. In the polyoxometalate $\mathrm{H}_{6}\left[\mathrm{Ca}\left(\mathrm{H}_{2} \mathrm{O}\right)_{7}\right]_{2}\left[\mathrm{Na}\left(\mathrm{H}_{2} \mathrm{O}\right)_{2}\right]_{2}\left[\mathrm{HBi}_{2} \mathrm{~W}_{20} \mathrm{O}_{70}\left(\mathrm{HWO}_{3}\right)\right] \cdot 14 \mathrm{H}_{2} \mathrm{O}$ (1) the molecule consists of two identical trilacunary $\beta$ $\left[\mathrm{BiW}_{9} \mathrm{O}_{33}\right]$ pseudo-Keggin type units in which three $\mathrm{W}_{3} \mathrm{O}_{13}$ groups is turned by $60^{\circ}$ relative to each other. Each $\mathrm{W}(\mathrm{VI})$ is hexacoordinated to oxygen with nine $\mathrm{W}$ octahedra sharing corners encapsulating the $\mathrm{Bi}(\mathrm{III})$ heteroatom inside the $\mathrm{W}_{9} \mathrm{O}_{33}$ unit $($ Figure 3). The $\mathrm{Bi}(\mathrm{III})$ itself is tricoordinated to $\mathrm{O}$ in a triangular based pyramidal units of $\mathrm{BiO}_{3}$ with one direction occupied by a lone pair of electrons. The two units are connected by two facial $\mathrm{O}_{2}(\mathrm{OH})$ and two $\mathrm{WO}_{2}$ groups or by two hydrated Na cations. Each W(VI) is hexacoordinated to oxygen with nine $\mathrm{W}$ octahedra sharing corners encapsulating the $\mathrm{Bi}(\mathrm{III})$ heteroatom inside the $\mathrm{W}_{9} \mathrm{O}_{33}$ unit (Fig. 3). The $\mathrm{Bi}(\mathrm{III})$ itself is tricoordinated to $\mathrm{O}$ in a triangular based pyramidal units of $\mathrm{BiO}_{3}$ with one direction occupied by a lone pair of electrons. The two units are connected by two facial $\mathrm{O}_{2}(\mathrm{OH})$ and two $\mathrm{WO}_{2}$ groups or by two hydrated $\mathrm{Na}$ cations.

Table 1 Crystal data and structure refinement for the crystals of three salts

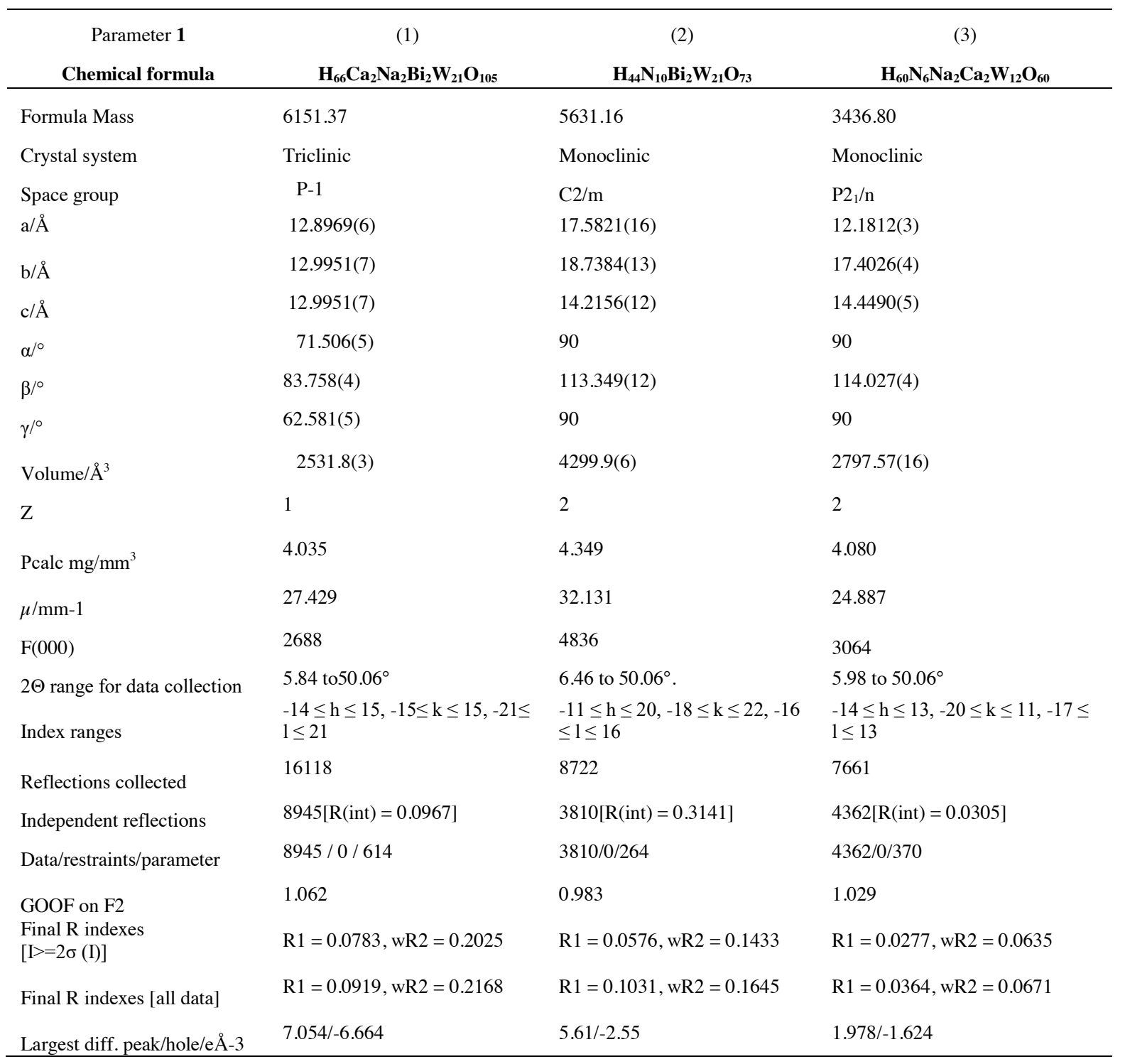




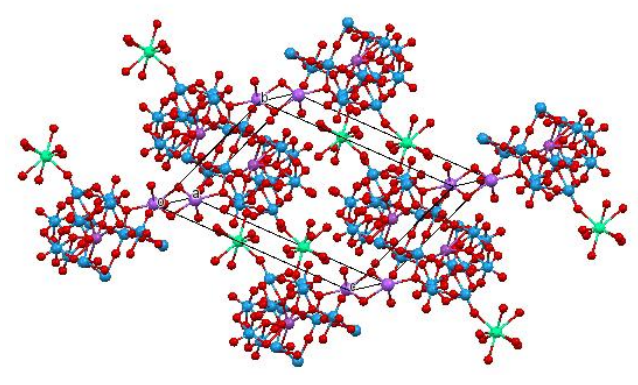

Fig. 2 Packing diagram showing 2D array of compound (1) in approximately the bc-plane (Bi gray, Na purple, Ca green).

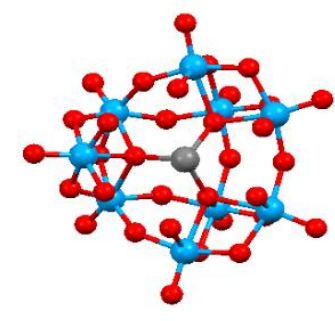

(a)

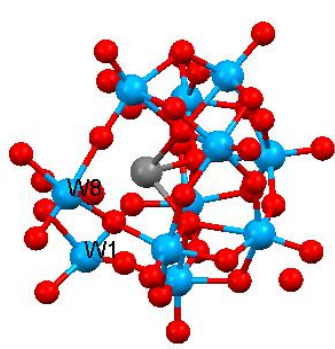

(b)
Fig. 3 Different views in compound (1) showing (a) the heteroatom Bi inside $\mathrm{W}_{9} \mathrm{O}_{33}$ octahedra cluster. (b) A side view with the bridging W8 and $\mathrm{W} 1$ atoms added to figure $\mathrm{A}$ (Bi gray $\mathrm{W}$ blue).

The three $\mathrm{Bi}-\mathrm{O}$ bonds in the $\mathrm{BiO}_{3}$ polyhedron are of length $2.097,2.141$ and $2.166 \mathrm{~A}^{\circ}$ with the O-Bi-O acute angles of $84.9,87.3,87.8^{\circ}$ indicating a large wedge around $\mathrm{Bi}$ of empty space probably occupied by a lone pair. The $\mathrm{W}(8)$ as well as $\mathrm{W}(1)$, are outside the BiW9O33 cage and bridge two cages together. The terminal W(8)-O bonds are in the range 1.700 to $2.117 \AA$ indicating double as well as single bonds. Probably the $\mathrm{O}(1 \mathrm{I})$ in the $\mathrm{W}(8)-\mathrm{O}(1 \mathrm{I})=2.117 \AA$ is protonated and of the type $\mathrm{W}-\mathrm{OH}$. An additional $\mathrm{W}(1)$ atom (occupancy 0.5) is outside the $\mathrm{BiW}_{9} \mathrm{O}_{33}$ cage with terminal W(1)-O distances in the range of 1.856 to $2.190 \AA$. The terminal W(1)-O(1J) of $2.190 \AA$ bond distances is again probably of the type $\mathrm{W}-\mathrm{OH}$. In the $\mathrm{W}_{9} \mathrm{O}_{33}$ cage, the $\mathrm{W}$ atoms are hexa-coordinated octahedral with the terminal $\mathrm{W}=\mathrm{O}$ bonds of length approximately $1.720 \AA$. The $\mathrm{W}-\mathrm{O}$ bond length of the bridging oxygen in the $\mathrm{W}-\mathrm{O}-\mathrm{W}$ groups are longer than the terminal $\mathrm{W}=\mathrm{O}$ bonds as expected, and with some of the bridging $\mathrm{O}$ atoms probably protonated as $\mathrm{OH}$. The group of nine octahedra in three groups of three share corners in Figure 4. There are at least seven $\mathrm{H}_{2} \mathrm{O}$ molecules per asymmetric unit that were located in the Fourier maps. Some additional water molecule, if present, will be badly disordered and if positioned exhibit very high isotropic thermal parameters. The $\mathrm{Ca}^{2+}$ is surrounded by eight $\mathrm{O}$ atoms in a square antiprismatic coordination with one of the eight $\mathrm{O}$ atoms, $\mathrm{O}(1 \mathrm{~K})$ bridging with $\mathrm{W}(3)$ of the $\mathrm{W}_{9} \mathrm{O}_{33}$ cage with $\mathrm{Ca}(1)-\mathrm{O}(1 \mathrm{~K})=2.520 \AA$. The $\mathrm{Ca}-\mathrm{O}$ bond distance range from 2.430 to $2.540 \AA$. Two $\mathrm{Na}^{+}{ }_{\text {(aq) }}$ bridge two $\mathrm{W}_{9} \mathrm{O}_{33}$ cages together.
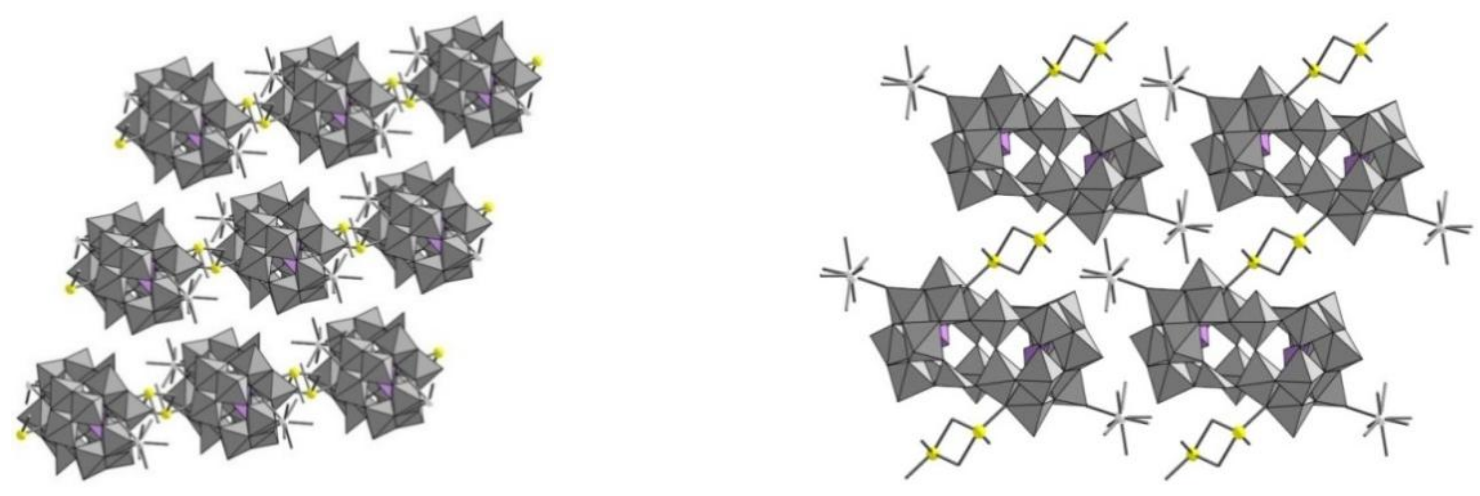

Fig. 4 W octahedra with Bi encapsulated in compound (1) Ca and Na coordination spheres are shown as lines.

In the case of case 2 Figure 5, the substance crystallizes in the space group $\mathrm{C} 2 / \mathrm{m}$, with two formula units per unit cell. The unit cell is monoclinic $\mathrm{C} 2 / \mathrm{m}$ with each formula unit occupying four asymmetric units. The anion $\left[\mathrm{HBi}_{2} \mathrm{~W}_{20} \mathrm{O}_{70}\left(\mathrm{HWO}_{3}\right)\right]^{12-}$ in 2 consists of two identical $\left[\mathrm{BiW}_{9} \mathrm{O}_{33}\right]$ Keggin type units, separated by a square of $\mathrm{W}_{4} \mathrm{O}_{8}$. Each $\mathrm{W}$ is hexacoordinated to $\mathrm{O}$ and each $\mathrm{Bi}(\mathrm{III})$ heteroatom is tricoordinated as a trigonalpyramidal $\mathrm{BiO}_{3}$ unit inside the $\mathrm{W}_{9} \mathrm{O}_{33}$ unit. The two $\left[\mathrm{BiW}_{9} \mathrm{O}_{33}\right]$ units are connected by four $\mathrm{WO}_{2}$ groups and two facial $\mathrm{WO}_{2}(\mathrm{OH})$. 
The three $\mathrm{Bi}-\mathrm{O}$ bonds in the trigonal $\mathrm{BiO}_{3}$ pyramid are two symmetryrelated $\mathrm{Bi}-\mathrm{O}=2.197 \AA$ and one $2.150 \AA$. The $\mathrm{O}-\mathrm{Bi}-\mathrm{O}$ angles are two symmetry-related $89.4^{\circ}$ and one $84.6^{\circ}$. For W(3) that joins the cages, two $\mathrm{W}(3)-\mathrm{O}$ bridging $\mathrm{W}(3)-\mathrm{O}(18)=2.191 \AA$ and two $\mathrm{W}(3)-\mathrm{O}(6)=1.767 \AA$ on the mirror plane. The two shorter values correspond to $\mathrm{W}=\mathrm{O}$ double bonds, while the longer values correspond to a protonated bridging $\mathrm{W}-\mathrm{OH}$ group. $\mathrm{W}(2)$ also falls on the plane between the two cages. the addenda/metal centers $\mathrm{Bi} / \mathrm{W}$ are linked via $\mathrm{W}-\mathrm{O}-\mathrm{W}$ and $\mathrm{Bi}-\mathrm{O}-\mathrm{W}$ oxygen bridged covalent bonds. The addenda atom is located in the center of nine distorted $\mathrm{WO}_{6}$ octahedra that are linked together. $\mathrm{W}(8)$ has 0.25 occupancy and will correspond to $\left(\mathrm{HWO}_{3}\right)^{+}$in the formula unit $\mathrm{H}_{2}\left[\mathrm{NH}_{4}\right]_{10}\left[\mathrm{HBi}_{2} \mathrm{~W}_{20} \mathrm{O}_{70}\left(\mathrm{HWO}_{3}\right)\right]$. W(8) falls lateral to the molecule as shown in Figure 6, and Figure 7

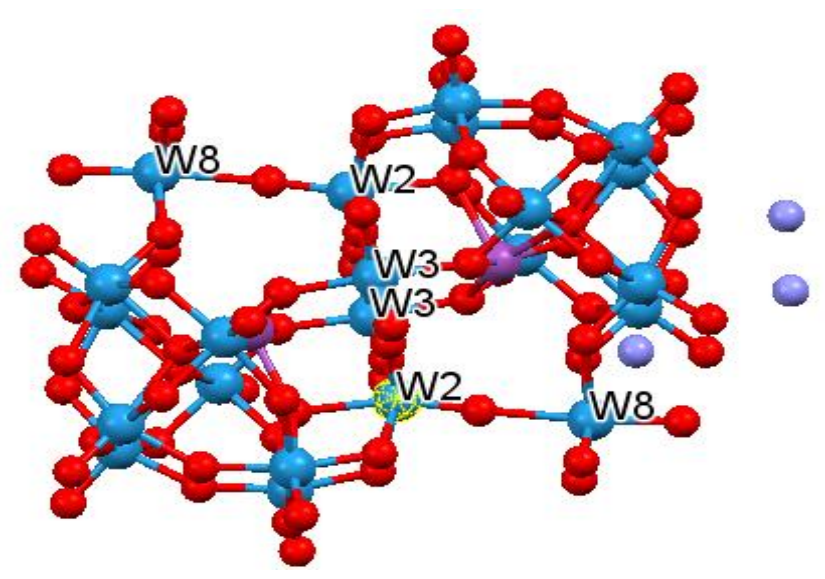

Fig. 6 Molecular unit showing the disposition of $\mathrm{W}(8)$ as well as $(\mathrm{W}(2)$ and $\mathrm{W}(3)$. Only $2.5 \mathrm{NH} 4^{+}$in one asymmetric unit is shown. (Bi gray, W blue. $\mathrm{N}$ light blue).

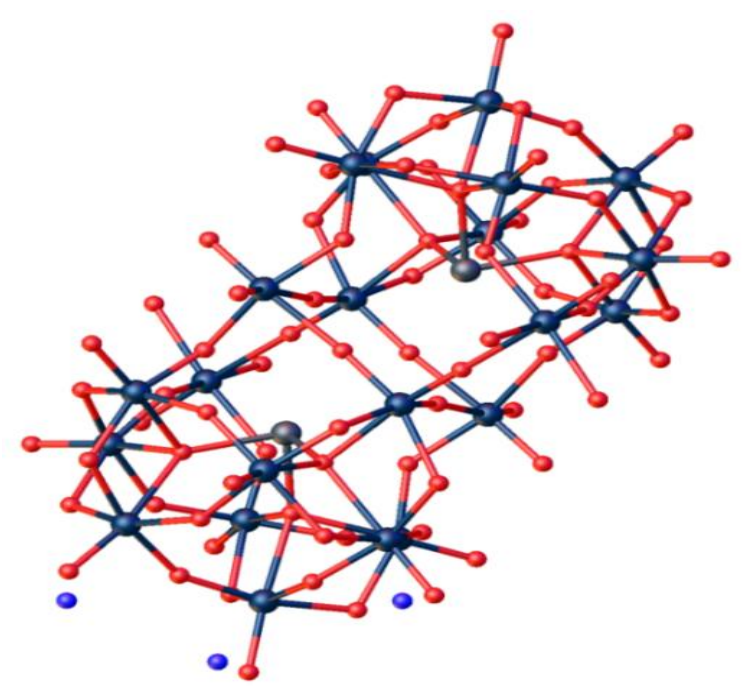

Fig. 5 The anion in compound (2) constituted from 4 asymmetric units. The $2.5 \mathrm{NH}_{4}{ }^{+}$that belong to one of the asymmetric units are also shown.

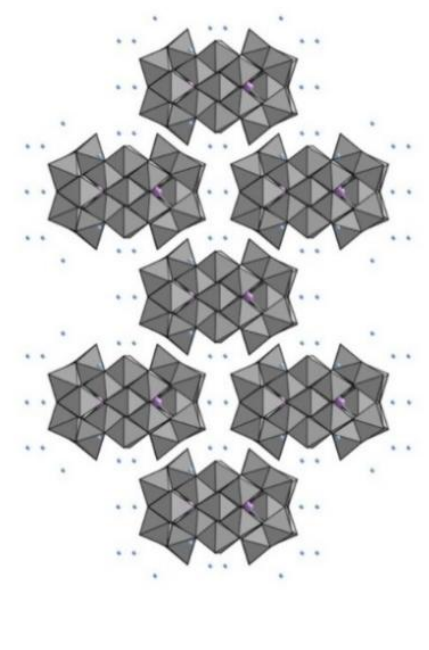

Fig. 7 Packing diagram of compound (2) in ab-plane showing W octahedra. $\mathrm{NH}_{4}{ }^{+}$cations are discrete.

Changing the preparation procedure of compound (2) by increasing the $\mathrm{pH}$ from 5.5 to 6 led to the production of a different polyoxometalate that did not contain $\mathrm{Bi}$, with a sodium $\mathrm{Na}\left(\mathrm{H}_{2} \mathrm{O}\right)_{4}$ and calcium $\left[\mathrm{Ca}\left(\mathrm{H}_{2} \mathrm{O}\right)_{4}\right]_{2}$ as linkers. The $\left[\mathrm{W}_{12} \mathrm{O}_{42}\right]^{12-}$ anion present in the structure indicates that a dynamic decomposition and reconstruction process happened during the reaction, where it was slowly reassembled from the $\mathrm{Na}_{11} \mathrm{H}\left[\mathrm{H}_{(2-\mathrm{x})} \mathrm{Bi}_{2} \mathrm{~W}_{20} \mathrm{O}_{70}\left(\mathrm{HWO}_{3}\right) \mathrm{x}\right] \cdot 46 \mathrm{H}_{2} \mathrm{O}$ precursor ( Figure 8).

The single-crystal X-ray also indicates that each polyanion $\left[\mathrm{W}_{12} \mathrm{O}_{42}\right]^{12-}$ in compound (3) coordinates with two identical calcium atoms via terminal oxygen atoms and each calcium cation bridges two $\left[\mathrm{W}_{12} \mathrm{O}_{42}\right]^{12-}$ anions Figure 9. Each calcium cation is only seven coordinated with oxygen atoms, two of which are bridging, in an approximately mono-capped trigonal prismatic geometry. The Ca-O bond lengths are in the range of 2.369 to $2.525 \AA$. 


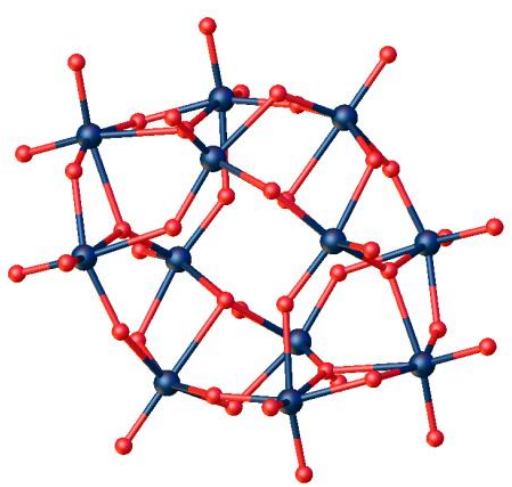

(a)

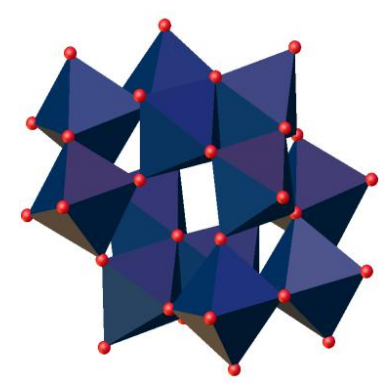

(b)
Fig. 8 The anion in compound (3), $\left[\mathrm{W}_{12} \mathrm{O}_{42}\right]^{12-}$, as tungstate polyhedra (a), and as ball and stick (b).

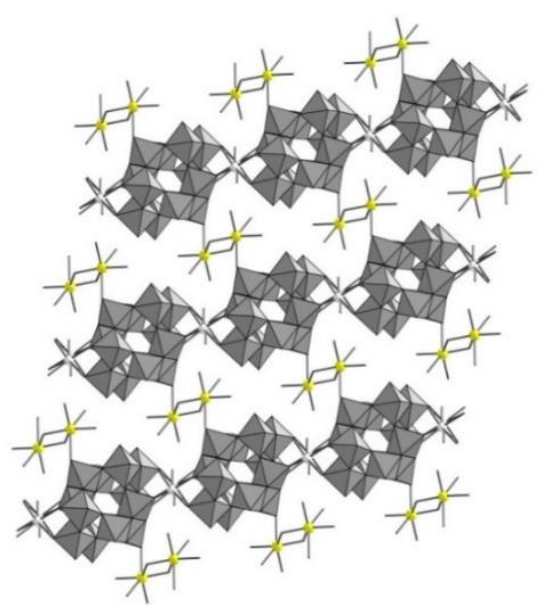

Fig. 9 Compound (3) showing the anionic W polyhedral units joint together into chains by hydrated $\mathrm{Ca}^{2+}$. The chains are built into layers by connecting hydrated $\mathrm{Na}^{+}$

\subsection{Electronic spectra}

In general, UV-visible spectra of polyoxometalate clusters without transition metals or lanthanides exhibit two charge transfer (CT) bands. These bands are characteristic of the polyoxoanionic framework and are ascribed to oxygen-to-metal charge transfer transitions. All compounds (1), (2), and (3) show identical UV spectra. The UV spectrum in Figure 10 shows one CT band, due to d $\pi$-p $\pi$-d $\pi$ transitions from the tricentric W-O-W bonds, while a shoulder recorded at $256 \mathrm{~nm}$. The spectrum point to another band that should appear below $200 \mathrm{~nm}$ which is attributed to $\mathrm{d} \pi$-p $\pi$ charge transfer transitions of the terminal $\mathrm{W}=\mathrm{O}$ bonds. This charge transfer is of the type $(\mathrm{W} \leftarrow \mathrm{O})$.
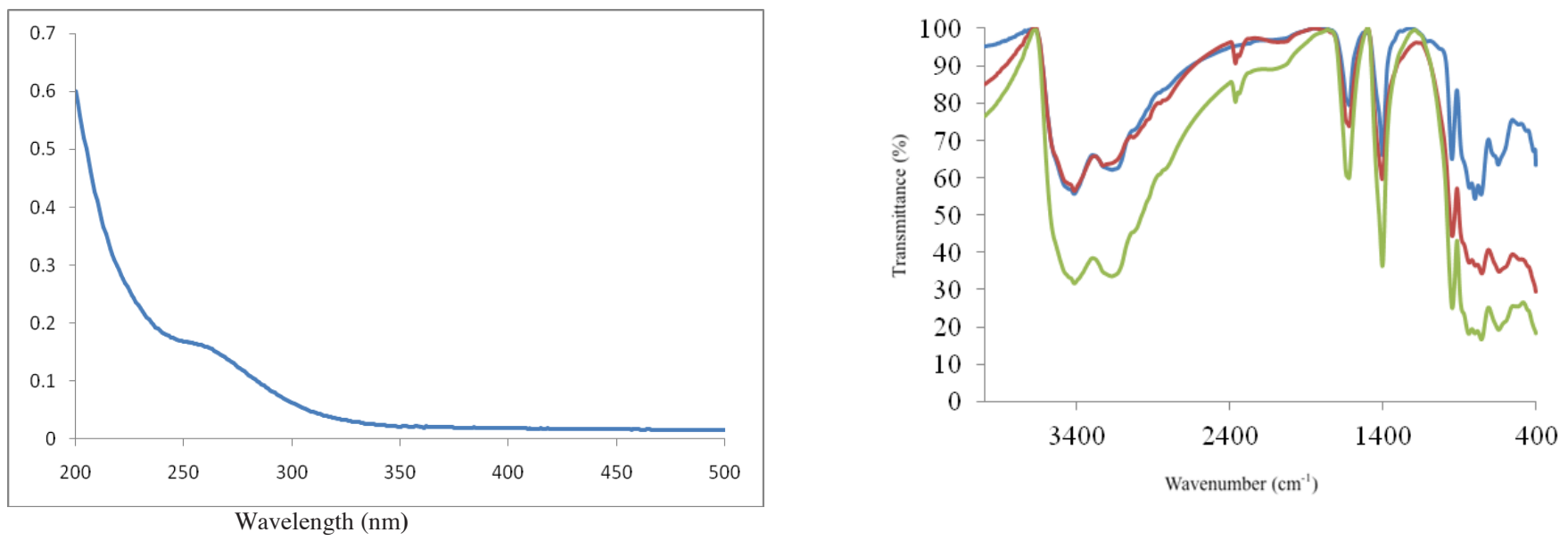

Fig. 10 UV-Visible spectra of compound (1), (2) and (3) spectra recorded at Fig. 11 FTIR spectra of compound (1) (red), (2) (blue), and (3) (green). random concentrations

The vibration bands of the FTIR spectrum of three compounds are strictly like Figure 11. The four characteristic asymmetric vibrations present are characteristic to the $\mathrm{W}-\mathrm{O}$ bonds are recorded in the $640-950 \mathrm{~cm}^{-1}$ range. The antisymmetric stretching vibrations (W-Ot) appear at $945 \mathrm{~cm}^{-1}$, and the two (W-Obrid) appear at, 798 and $754 \mathrm{~cm}^{-1}$, very strong bands at $1633 \mathrm{~cm}^{-1}$ is assigned to H-O$\mathrm{H}$ bending and two bands ascribed to the presence of hydrogen-bonded $\mathrm{O}-\mathrm{H}$ stretching modes at 3415 and $3174 \mathrm{~cm}^{-1}$. 


\subsection{Thermogravimetric Analysis}

Thermal stability of the compound (3) was determined by TGA measurements (Figure 12). No significant change takes place from $800-1200 \mathrm{C}^{\circ}$. At $1212.12 \mathrm{C}^{\circ}$ the residual mass is measured to be $87.89 \%$. The calculated $\% \mathrm{H}_{2} \mathrm{O}$ and $\mathrm{NH}_{4}{ }^{+}$in the proposed and determined formula $\left[\mathrm{NH}_{4}\right]_{6}\left[\mathrm{Na}\left(\mathrm{H}_{2} \mathrm{O}\right)_{4}\right]_{2}\left[\mathrm{Ca}\left(\mathrm{H}_{2} \mathrm{O}\right)_{4}\right]_{2}\left[\mathrm{~W}_{12} \mathrm{O}_{42}\right] .2 \mathrm{H}_{2} \mathrm{O}(3)$ is $12.6 \%$ in close agreement with $\%$ mass loss in TGA.

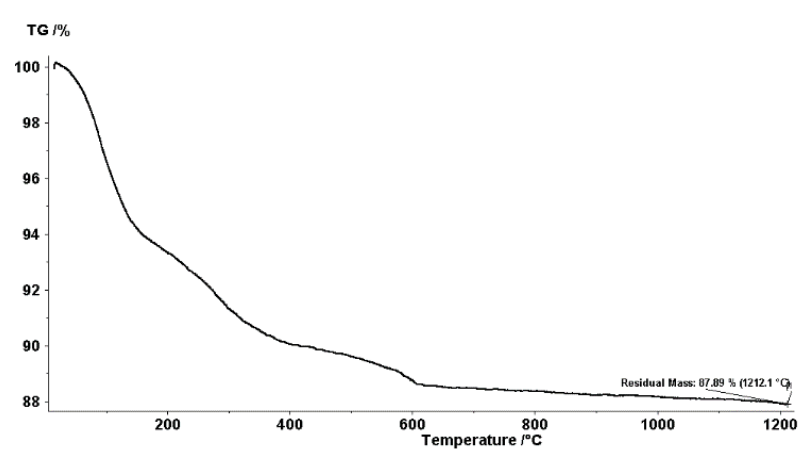

Fig. 12 Thermogravimetric analysis (TGA) of compound $\left[\mathrm{NH}_{4}\right]_{6}\left[\mathrm{Na}\left(\mathrm{H}_{2} \mathrm{O}\right)_{4}\right]_{2}\left[\mathrm{Ca}\left(\mathrm{H}_{2} \mathrm{O}\right)_{4}\right]_{2}\left[\mathrm{~W}_{12} \mathrm{O}_{42}\right] 2 \mathrm{H}_{2} \mathrm{O}(3)$.

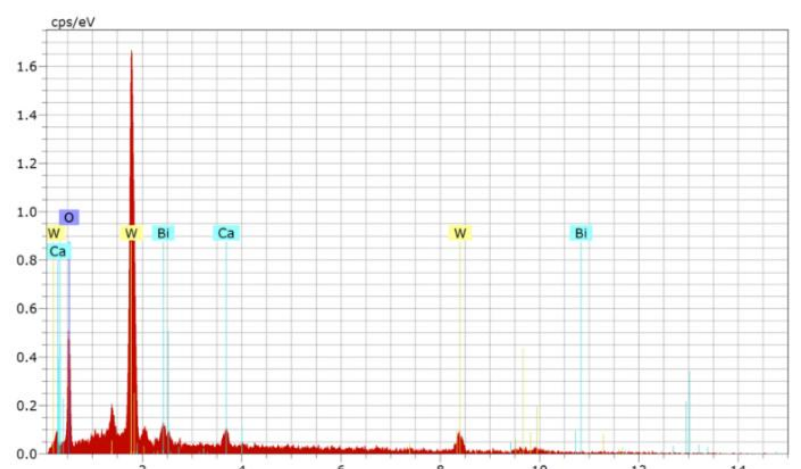

Fig. 13 EDS mapping of ${ }^{2}(1) \mathrm{H}_{6}\left[\stackrel{4}{\mathrm{Ca}}\left(\mathrm{H}_{2} \mathrm{O}\right)_{7}\right]_{2}\left[\mathrm{Na}\left(\mathrm{H}_{2} \mathrm{O}\right)_{2}\right]_{2}\left[\mathrm{HBi}_{2} \mathrm{~W}_{20} \mathrm{O}_{70}\left(\mathrm{HWO}_{3}\right)\right] 14 \mathrm{H}_{2} \mathrm{O}(1)$.

\subsection{Analysis Energy-dispersive X-ray spectroscopy (EDS) mapping}

More than one spot on the surface of one crystal was used for analysis by EDS and was confirmed to give identical results. The EDS mapping of (1) Figure 13 confirms the existence of $\mathrm{O}, \mathrm{W}, \mathrm{Bi}$, and Ca within the crystal.

\section{Conclusions}

This work reports the synthesis and structural investigation of three new polyoxometalate based in the polyanion $\left[\mathrm{HBi}_{2} \mathrm{~W}_{20} \mathrm{O}_{70}\left(\mathrm{HWO}_{3}\right)\right]^{12}$. This lead to the formation of three new crystalline products, the last of which did not contain Bi. These are $\mathrm{H}_{6}$ $\left[\mathrm{Ca}\left(\mathrm{H}_{2} \mathrm{O}\right)_{7}\right]_{2}\left[\mathrm{Na}\left(\mathrm{H}_{2} \mathrm{O}\right)_{2}\right]_{2}\left[\mathrm{HBi}_{2} \mathrm{~W}_{20} \mathrm{O}_{70}\left(\mathrm{HWO}_{3}\right)\right] .14 \mathrm{H}_{2} \mathrm{O} \quad(1), \quad \mathrm{H}_{2}\left[\mathrm{NH}_{4}\right]_{10}\left[\mathrm{HBi}_{2} \mathrm{~W}_{20} \mathrm{O}_{70}\left(\mathrm{HWO}_{3}\right)\right] \quad$ and $\left[\mathrm{NH}_{4}\right]_{6}\left[\mathrm{Na}\left(\mathrm{H}_{2} \mathrm{O}\right)_{4}\right]_{2}\left[\mathrm{Ca}\left(\mathrm{H}_{2} \mathrm{O}\right)_{4}\right]_{2}\left[\mathrm{~W}_{12} \mathrm{O}_{42}\right] .2 \mathrm{H}_{2} \mathrm{O}(3)$. Three structures were reported in this work differs in their unit cell and space group the last one does not contain bismuth. The structure of compound $\mathrm{H}_{66} \mathrm{Ca}_{2} \mathrm{Na}_{2} \mathrm{Bi}_{2} \mathrm{~W}_{21} \mathrm{O}_{105}$ has the lowest lattice symmetry amongst all. It crystallizes in the space group $\quad \mathrm{P}-1$, with one molecular per unit cell, while 2 and 3 crystallize in monoclinic space groups $\mathrm{C} 2 / \mathrm{m}$ and $\mathrm{P} 21 / \mathrm{n}$ respectively. Our work provides a new strategy to have a calcium-containing polyanion $\left[\mathrm{HBi}_{2} \mathrm{~W}_{20} \mathrm{O}_{70}\left(\mathrm{HWO}_{3}\right)\right]^{12-}$ with differ lattice symmetry.

Nomenclature

$\begin{array}{lll}\text { EDS } & =\text { Energy-dispersive spectroscopy } & {[-]} \\ \text { TGA } & =\text { Thermogravimetric Analysis } & {[-]} \\ \text { SEM } & =\text { Scanning Electron Microscopy } & {[-]} \\ \text { UV } & =\text { Ultraviolet } & {[\mathrm{nm}]}\end{array}$

\section{Acknowledgment}

This work was supported by the University of Jordan (Department of Chemistry) we extend our sincere thanks and appreciation to all the people who made structural determination by single-crystal x-ray diffraction at Hamdi Mango center, The University of Jordan possible. 


\section{References}

Allmen, D., Grundmann, H., Linden, A., and Patzke, G., "Synthesis and Characterization of 0D-3D Copper-Containing Tungstobismuthates Obtained from the Lacunary Precursor $\mathrm{Na}_{9}\left[\mathrm{~B}-\alpha-\mathrm{BiW}_{9} \mathrm{O}_{33}\right] "$, Inorg. Chem., 56, 327-335 (2017).

Allmen, D., Moré, R., Müller, R., Soriano-López, J., Linden, A., and Patzke, G., "Nickel-Containing Keggin-Type Polyoxometalates as Hydrogen Evolution Catalysts: Photochemical Structure-Activity Relationships", Chem. Plus Chem., 80, 1389-1398 (2015).

Breitwieser, R., Auvray, T., Volatron, F., Salzemann, C., Ngo, A., Albouy, P., Proust, A., and Petit, C., "Binary Superlattices from Mo132 Polyoxometalates and Maghemite Nanocrystals: Long-Range Ordering and Fine-Tuning of Dipole Interactions", Small. 12, 220-228 (2016).

Chen, W., Tan, H., and Wang, E., "The chirality and bionic studies of polyoxometalates: the synthetic strategy and structural chemistry", J. Coord. Chem., 65, $1-18$ (2012).

Clemente-Juan, J., Coronado, E., and Gaita-Arino, A., "Magnetic polyoxometalates: from molecular magnetism to molecular spintronics and quantum computing", Chem. Soc. Rev., 41, 7464-7478 (2012).

Evangelisti, F., Car, P., Blacque, O., and Patzke, G., "Photocatalytic water oxidation with cobalt-containing tungstobismutates: tuning the metal core" Catal. Sci. Technol., 3, 3117-3129 (2013).

Hasenknopf, B., "Polyoxometalates Introduction to a class of inorganic compounds and their biomedical applications", Front. Biosci., 10, $275-287$ (2005).

Hussain, F., Saini, M., Gupta, R., and Singh, S., "Yttrium Containing Dimeric and Tetrameric Keggin Type Phosphotungstates: Syntheses, Crystal Structure and Catalytic Activity for Alcohol Oxidation Using $\mathrm{H}_{2} \mathrm{O}_{2}$ as an Oxidant in Water", Curr. Catal., 5, 66-76 (2016).

Hutin, M., Rosnes, M., Long, D., and Cronin, L., "Polyoxometalates: Synthesis and Structure - From Building Blocksto Emergent Materials. In Comprehensive Inorganic Chemistry II", $2^{\text {nd }}$ Ed., Elsevier, Amsterdam, 241-269 (2013).

Krebs, B., and Klein, R., "Synthesis and structural chemistry of novel heteropolymolybdates and -tungstates" Mol. Eng., 3, 43-59, (1993).

Kortz, U., Müller, A., Van Slageren, J., Schnack, J., Dalal, N., and Dressel, M., "Polyoxometalates: Fascinating structures, unique magnetic properties", Coord. Chem. Rev., 253, 2315-2327 (2009).

Lai, T., Awada, M., Floquet, S., Roch-Marchal, C., Watfa, N., Marrot, J., Haouas, M., Taulelle, F., and Cadot, E., "Tunable Keplerate Type-Cluster "Mo132" Cavity with Dicarboxylate Anions" Chem. Eur. J., 21, 13311-13320 (2015).

Liu, R., Zhang, G., Cao, H., Zhang, S., Xie, Y., Haider, A.; Kortz, U., Chen, B., Dalal, N., Zhao, Y., Zhi, L., Wu, C.; Yan, L.; Su, Z., and Keita, B. "Enhanced proton and electron reservoir abilities of polyoxometalate grafted on graphene for high-performance hydrogen evolution" Ener. Env. Sci.,9, 1012-1023 (2016).

Long, D., Tsunashima, R., and Cronin, L., "Polyoxometalates Building Blocks for Functional Nanoscale Systems", Angew. Chem., Int. Ed. 49, 1736-1758 (2010).

Lv, H.; Song, J.; Zhu, H., Geletii, Y., Bacsa, J., Zhao, C., Lian, T., Musaev, D., and Hill, C., "Visible-light-driven hydrogen evolution from water using a noblemetal-free polyoxometalate catalyst" J. Catal., 307, 48-54 (2013).

Mansergh, R., Fullmer, L., Park, D., Nyman, M., and Keszler, D., "Reaction Pathway: Aqueous Hexatantalate Clusters to High-Density Tantalum Oxide Nanofilms", Chem. Mater., 28, 1553-1558, (2016).

Miras, H., Yan, J., Long, D., and Cronin, L., "Engineering polyoxometalates with emergent properties", Chem. Soc. Rev. 41, $7403-7430$ (2012).

Ni, L., Patscheider, J., Baldridge, K., and Patzke, G., "New Perspectives on Polyoxometalate Catalysts: Alcohol Oxidation with Zn/Sb-Polyoxotungstates", Chem. Eur. J., 18, 13293-13298 (2012).

Ozawa, Y., and Sasaki, Y., "Synthesis and crystal structure of $\left[\left(\mathrm{CH}_{3}\right)_{4} \mathrm{~N}_{6}\left[\mathrm{H}_{3} \mathrm{BiW}_{18} \mathrm{O}_{60}\right]\right.$ ", Chem. Lett., 16, 923-926 (1987).

Patrut, A., Bogge, H., Forizs, E., Rusu, D., Lowy, D., Margineaanu, D., and Naumescu, A., "Spectroscopic and Crystal structural investigation of a new Bismuth (III) containing polyoxometalate cluster ", Rev. Roum. Chim, 55, 865-870 (2010).

Patrut, A., Margineanu, D., Lowy, D., Kogerler, P., Schmidtmann, M., and Boegge, H., "Spectroscopic, magnetic and crystal structure investigation of a new pseudo-Dawson nano-sized polyoxometalate cluster with mixed addenda", J. of Optoel. and Adv. Mater., 9, 3921-3926 (2007).

Rasmussen, M., Nather, C., Van Leusen, J., Warzok, U., Schalley, C., Kogerler, P., and Bensch, W., "Beautiful and magnetically exotic: $\left\{\mathrm{V}_{4} \mathrm{~W}_{2}\right\}$ and $\left\{\mathrm{V}_{4} \mathrm{~W}_{4}\right\}$ type polyoxometalates", Dalton Trans. 45, 10519-10522 (2016).

Rausch, B., Symes, M., Chisholm, G., and Cronin, L., "Decoupled catalytic hydrogen evolution from a molecular metal oxide redox mediator in water splitting", Sci., 345, 1326-1330 (2014).

Rodewald, D., and Jeannin, Y., "Two new bismutho(III)polytungstates, $\mathrm{Na}_{10}\left[\mathrm{Bi}_{2} \mathrm{Ni}_{2} \mathrm{~W}_{20} \mathrm{O}_{70}\left(\mathrm{H}_{2} \mathrm{O}\right)_{6}\right] .26 \mathrm{H}_{2} \mathrm{O}$ and $\mathrm{Na}_{8}\left[\mathrm{Bi}_{2} \mathrm{~W}_{22} \mathrm{O}_{70}(\mathrm{OH})_{6}\right] .31 \mathrm{H}_{2} \mathrm{O}$ ", Comptes Rendus de l'Academie des Sciences, Serie Chimie, 1, 175-181 (1998).

Rusu, D., Craciun, C., Barra, A., David, L., Rusu, M., Rosu, C., Cozar, O., and Marcu, G., "Spectroscopic and electron paramagnetic resonance behavior of trinuclear metallic clusters encapsulated in $\left[\mathrm{Mn}^{+3}\left(\mathrm{H}_{2} \mathrm{O}\right) \mathrm{x}\left(\mathrm{BiW}_{9} \mathrm{O}_{33}\right)_{2}\right]^{(18-3 \mathrm{n})-}$ heteropolyanion $\left(\mathrm{M}^{\mathrm{n}+}=(\mathrm{VO}) \mathrm{II}, \mathrm{x}=0\right.$, and $\mathrm{M}^{\mathrm{n}+}=\mathrm{CrIII}, \mathrm{MnII}, \mathrm{FeIII}, \mathrm{CoII}$, NiII, CuII, x = 3)" , J. of the Chem. Soc., Dalton Tran., 19 , 2879-2887 (2001).

Schwarz, B., Forster, J., Goetz, M., Yücel, D., Berger, C., Jacob, T., Streb, C., "Visible-Light-Driven Water Oxidation by a Molecular Manganese Vanadium Oxide Cluster", Angew. Chem., Int. Ed. 55, 6329-6333 (2016).

Vonci, M., and Boskovic, C., "Polyoxometalate-Supported Lanthanoid Single-Molecule Magnets", Aust. J. Chem., 67, 1542-1552 (2014).

Wang, J., Zhang, H., Huang, C., Yu, H. Sun, Z., and Sun, Q. "Synthesis and crystal structure of the heteropolymate compound $\mathrm{Na}_{3} \mathrm{H}_{2}\left[\mathrm{Ce}_{3}\left(\mathrm{H}_{2} \mathrm{O}\right)_{18} \mathrm{Bi}_{2} \mathrm{~W}_{22} \mathrm{O}_{76}\right] 23 \mathrm{H}_{2} \mathrm{O}$ ", Chin. J. Struct. Chem, 23 , 902-907 (2004).

$\mathrm{Yu}, \mathrm{L}$., Ding, Y., Zheng, M., Chen, H., and Zhao, J. " $\beta\left[\mathrm{SiNi}_{2} \mathrm{~W}_{10} \mathrm{O}_{36}(\mathrm{OH})_{2}\left(\mathrm{H}_{2} \mathrm{O}\right)_{4}\right]^{24-}$ : A new robust visible light-driven water oxidation catalyst based on nickelcontaining polyoxometalate", Chem. Commun. 52, 14494-14497 (2016). 